\title{
WC-Co Particles Reinforced Aluminum Matrix by Conventional and Microwave Sintering
}

\author{
Ehsan Ghasali, ${ }^{a, b *}$,Amir Hossein Pakseresht", Maryam Aghelic, Amir Hossein Marzbanpour ${ }^{b}$, \\ Touradj Ebadzadeh ${ }^{a}$
}

${ }^{a}$ Ceramic Department Materials and Energy Research Center, Imam Khomeini Blvd, Meshkin-Dasht, P.O. Box 31787-316, Karaj, Iran

${ }^{b}$ Sama Technical and Vocational Training College, Islamic Azad University, Eslamshahr, Tehran, Iran ${ }^{c}$ Department of Materials Engineering, Semnan University, P.O. Box 35131-19111, Semnan Province, Iran

Received: July 12, 2015; Revised: October 1, 2015

\begin{abstract}
Metal matrix composites of Al-WC (10,15 and $20 \mathrm{wt} \%)$ were prepared by microwave (without holding) and conventional sintering (held for 1 hour) processes at various temperatures between $650-950{ }^{\circ} \mathrm{C}$. The results indicated that the highest density of conventional and microwave sintering corresponds to $97.4 \pm 1.2 \%$ and $98.6 \pm 0.8$ of theoretical density, respectively; The highest bending strength of conventional and microwave sintered samples were $223 \pm 12$ and $256 \pm 12 \mathrm{MPa}$, respectively. $\mathrm{XRD}$ patterns showed the decomposition of WC particles and formation of $\mathrm{Al}_{5} \mathrm{~W}$ and $\mathrm{Al}_{12} \mathrm{~W}$ interfacial reaction product phases in both processes. SEM studies showed that $\mathrm{WC}$ reinforcement particles were more likely to be agglomerated in microwave compared to conventional sintering process.
\end{abstract}

Keywords: metal matrix composite, tungsten carbide, aluminum, microwave sintering

\section{Introduction}

Particulate reinforced aluminum matrix composites (PRAMC) have received considerable attention because of high specific modulus, low coefficient of thermal expansion, good wear resistance and their high specific strength. These brilliant properties of PRAMC make them promising candidates for use in aerospace and automobile industries.

The PRAMCs have been usually produced via powder metallurgy and casting, while achieving a homogenous distribution of reinforcement in the base alloy in comparison with casting technique ${ }^{1}$. Low density, high conductivity and high toughness accompanied by a low price made aluminum as one of the best materials in some metal matrix composites in comparison with other light metals such as magnesium $(\mathrm{Mg})^{2}$. The corrosion resistance of aluminum is the other characteristic which is very important for use in PRAMC composites in different environments. In spite of all these advantages, the low tensile strength of aluminum has limited its applications ${ }^{3}$.

Ceramic particles (e.g. $\mathrm{Al}_{2} \mathrm{O}_{3}, \mathrm{SiC}, \mathrm{TiC}$ and WC) have been added to aluminum matrix in order to overcome its low tensile strength and increase hardness and tolerate temperatures.

Tungsten carbide (WC) is a $6 \mathrm{~B}$ transition metal carbide which has superior properties such as high hardness, high wear and corrosion resistance that makes it appropriate choice for reinforcement applications $\mathrm{s}^{4}$.

Using powder metallurgy method to produce aluminum composites reinforced with ceramic particles such as $\mathrm{SiC}$

*e-mail: ehsan_ghasali@yahoo.com will result in a homogenous distribution of reinforcement in the matrix, which in comparison with other methods like casting and thixoforming has fewer problems ${ }^{5}$. Reinforcement segregation, clustering, high localized residual porosity and poor interfacial bonding are problems found in other forming techniques ${ }^{6}$. The rest of the composite production methods such as spray deposition are expensive which render their applications ${ }^{7}$. Producing net-shape components and minimizing machining process are the other advantages of using powder metallurgy. In aluminum metal matrix composites, machining process is an important problem as a result of high tool wear due to the inherent abrasiveness of the hard ceramic (e.g. SiC) particles. On the other hand, the determining step in metallurgy powder process is the best method for sintering process ${ }^{8}$.

Nowadays microwave sintering of ceramics has received more attention due to its specific characteristics ${ }^{9}$. In conventional heating method slow heating rates and long dwell times during a sintering cycle result in exaggerated grain growth phenomenon. The microwave heating is the volumetric process and very efficient to obtain a very high heating rate due to the interaction of microwaves with ceramic materials. A fraction of the time required to complete microwave rather than conventional sintering. In microwave heating, the rate of grain growth decreases due to a decrease in sintering time. Therefore, samples sintered in a microwave process obtain a uniform microstructure with small grains and consequently, a high mechanical strength ${ }^{10}$.

Microwave heating has been extensively used for ceramics sintering and hard metals treatments, but for the 
first time Roy et al. ${ }^{11}$ reported the effective coupling of microwaves and metals in powder form. On the other hand, B. Gnanasundarajayaraja $\mathrm{a}^{2}$ investigated the effect of WC additions on aluminum metal matrix sintering by conventional heating. In the present work, the effect of Co particles additions on the interfacial reaction of aluminum-tungsten carbide composites has been studied. The resulting microstructure and mechanical properties of final composites sintered by conventional and microwave methods have been investigated.

\section{Experimental Procedures}

In this research, WC powder $(99.5 \%$ purity, $1 \mu \mathrm{m}$ average particle size) is reinforced with the base aluminum powder (1056-merck). Cobalt powder with purity of $99.8 \%$ and mean particle size of $5 \mu \mathrm{m}$ was used as additive. The required amounts of $\mathrm{Al}, \mathrm{WC}$ and Co powders were taken in three separated batches with the compositions given in Table 1.

The batches were prepared through mixing the determined of powders using Spex (Mixer mill-8000D). In the next step, the bar shape samples with the dimensions of $25 * 5 * 5 \mathrm{~mm}$ were compacted at $250 \mathrm{MPa}$ using a uniaxual press. Microwave and conventional sintering were performed at 650, 750, 850 and $950{ }^{\circ} \mathrm{C}$ in graphite bed without holding and held for 1 hour, respectively. Densities of sintered samples were measured using Archimedes method. Three point bending strength of samples were examined with Santam-STm 20 and X-ray diffraction analyses were performed by Philips X' Pert System to determine the phases in sintered samples. Microstructural investigations of sintered samples were carried out using a SEM (Stereoscan 360, Leica Cambridge).

\section{Result and Discussion}

Figures 1 and 2 show the variation of relative density versus temperature for microwave and conventional sintered samples. As Figure 1 shows the highest relative density corresponded to A series of samples which have lower amounts of reinforcement among the other series of samples. Increasing sintering temperature had no positive effect on the relative density of samples and the maximum density was achieved at $650{ }^{\circ} \mathrm{C}$.

Figure 2 shows the increase of relative density ( $\pm 0.8 \%$ standard deviation) of conventional sintered samples with the increasing sintering temperature. It seems that longer sintering time in conventional process makes more diffusion time for aluminum atoms to promote sintering process for higher relative density. The highest relative density corresponds to A series of samples which similar to microwave sintered specimens.

Figures 3 and 4 demonstrate the XRD diffraction patterns of microwave and conventional sintered of $\mathrm{C}$ series samples. As expected, the peaks corresponding to $\mathrm{Al}$ and WC are indentified in the XRD pattern. In XRD patterns of

Table 1. Different compositions of batches.

\begin{tabular}{cccc}
\hline series & Al (wt \%) & WC (wt \%) & Co (wt \%) \\
\hline A series & 89 & 10 & 1 \\
B series & 83.5 & 15 & 1.5 \\
C series & 78 & 20 & 2 \\
\hline
\end{tabular}

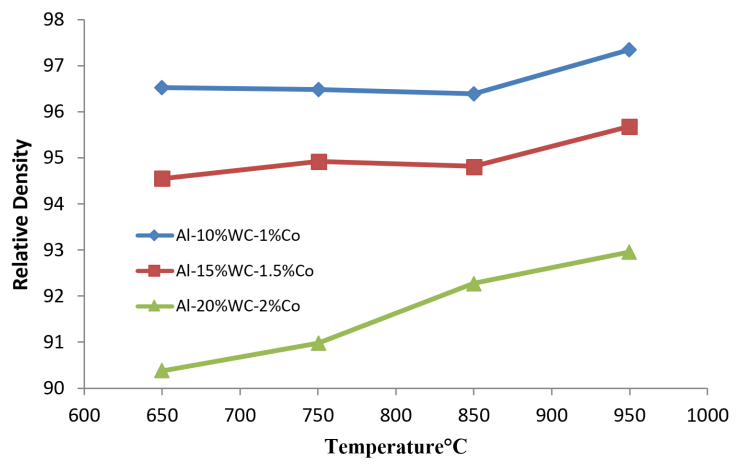

Figure 1. Variation of relative density vs temperature in microwave process.

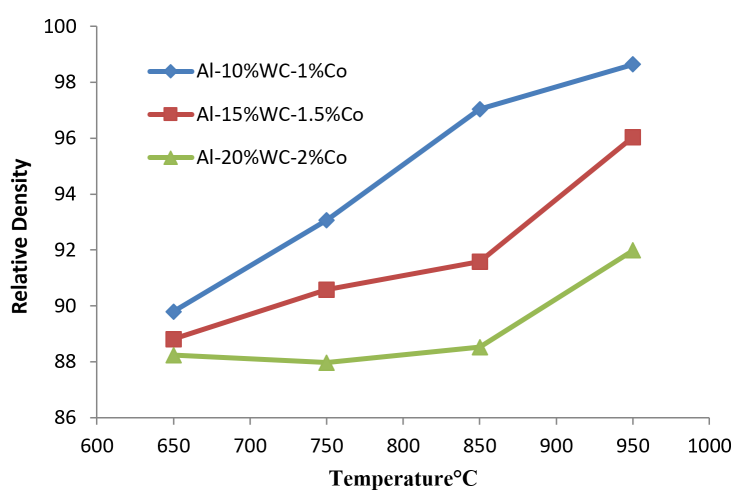

Figure 2. Variation of relative density versus temperature in conventional process.

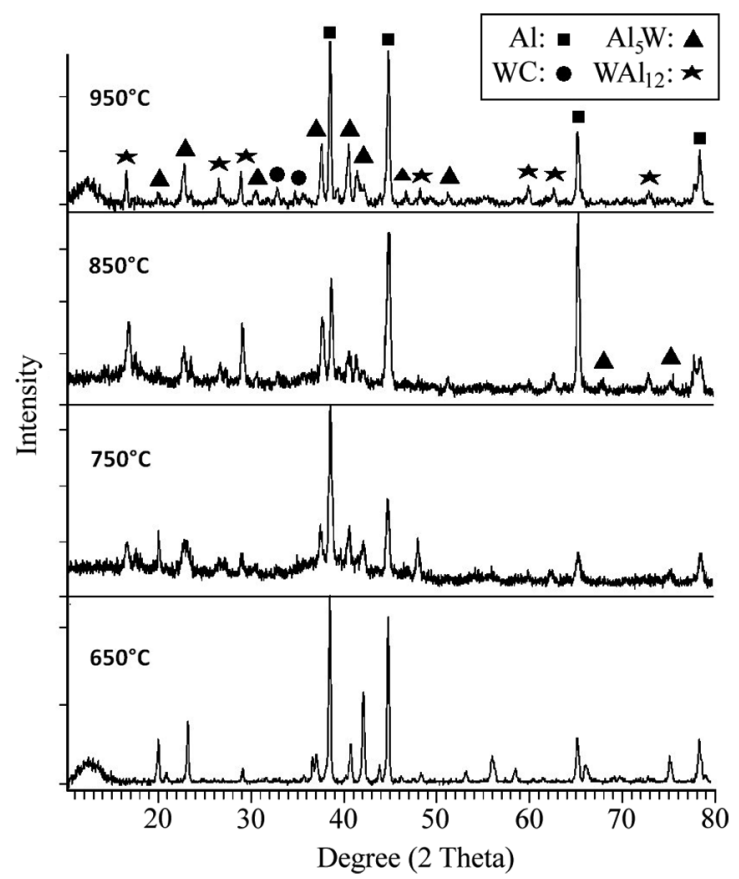

Figure 3. XRD patterns of microwave sintered samples at 650 , 750,850 and $950{ }^{\circ} \mathrm{C}$. 
microwave-sintered samples (Figure 3), two intermetallic phases marked as $\mathrm{Al}_{5} \mathrm{~W}$ and $\mathrm{Al}_{12} \mathrm{~W}$ were detected after sintering at 650 and $750{ }^{\circ} \mathrm{C}$. In Figure 5, it seems that $\mathrm{Al}_{5} \mathrm{~W}$ solid solution is formed as the result of the decomposition of WC $(20 \% \mathrm{wt})$. But probably the rapid heating and cooling rate of microwave process resulted in the formation of low amounts of $\mathrm{Al}_{12} \mathrm{~W}$.

It is obvious that that temperature plays a vital role in the interface reaction of Al-WC composite materials. During sintering process, matrix alloy in liquid state permeates into

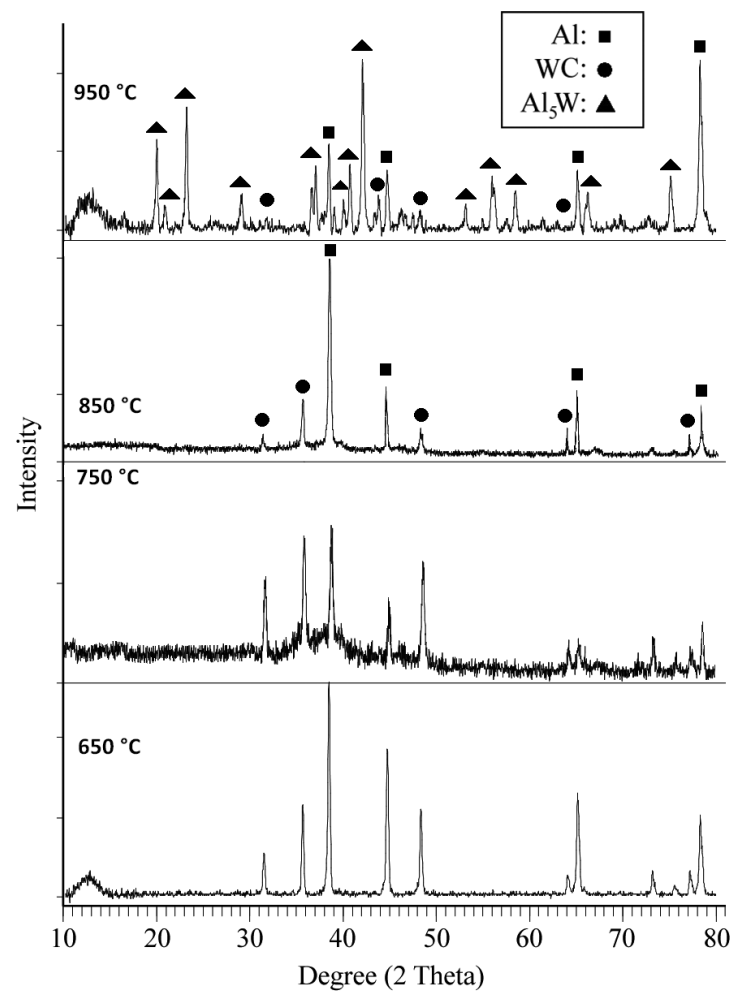

Figure 4. XRD patterns of conventional sintered samples at 650 , 750,850 and $950^{\circ} \mathrm{C}$.

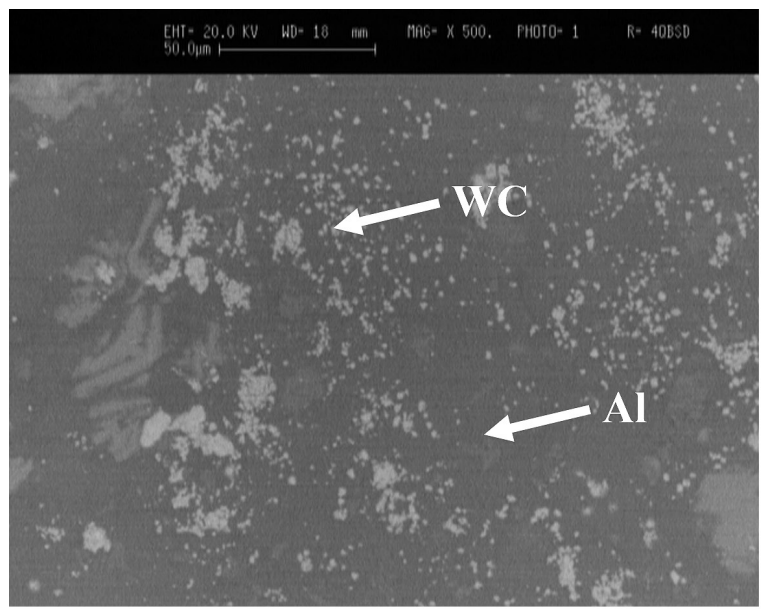

(a) interspaces of WC particles and their surfaces, and touches WC particles tightly. In this case, thermal decomposition reaction takes place on the edges and surfaces of WC particles. These probable interface reactions can be described by the following reactions ${ }^{12}$ :

$\mathrm{WC} \rightarrow \mathrm{W}+\mathrm{C}$

Since $\mathrm{W}_{2} \mathrm{C}$ is in metastable phase under preparation temperature, a possible phase change can occur as follows:

$\mathrm{W}_{2} \mathrm{C} \rightarrow \mathrm{WC}+\mathrm{W}$

$\mathrm{W}$ atoms produced in reaction (1) and (2) leave the surfaces of WC particles and enter into the liquid phase of matrix alloys. When the concentration of $\mathrm{W}$ atoms in liquid phase exceeds its maximum solubility, $\mathrm{Al}_{12} \mathrm{~W}$ compound comes into being:

$$
\mathrm{W}+12 \mathrm{Al} \rightarrow \mathrm{WAl}_{12}
$$

As preparation temperature increases, the phase change takes place in $\mathrm{Al}_{12} \mathrm{~W}$ and $\mathrm{Al}_{5} \mathrm{~W}$ forms:

$$
\mathrm{WAl}_{12} \rightarrow \mathrm{Al}_{5} \mathrm{~W}+7 \mathrm{Al}
$$

Most researchers believe that carbon reacts with $\mathrm{Al}$ to form $\mathrm{Al}_{4} \mathrm{C}_{3}$ at the interface reaction. In the present work, $\mathrm{Al}_{4} \mathrm{C}_{3}$ can be formed at interface due to the thermal decomposition of $\mathrm{WC}$ and the formation of carbon. However, $\mathrm{Al}_{4} \mathrm{C}_{3}$ peaks were not detected by XRD analysis probably due to the low amount of formed $\mathrm{Al}_{4} \mathrm{C}_{3}$.

Figure 4 shows the more intense peaks of $\mathrm{Al}_{5} \mathrm{~W}$ phase formed at $950{ }^{\circ} \mathrm{C}$ in conventional compared to microwave heating due to a lower heating rate and longer holding time in the former. Microwave heating provides higher temperature at the interface of $\mathrm{Al}$ and $\mathrm{WC}$ particles than entire volume of sample because of superior absorption of microwaves at the surface of WC particles which lead to accelerating the reactions as reported above.

Structures and lattice parameters of intermediate phases are listed in Table 2. By decomposition of supersaturated (Al) solid solutions, two intermediate phases were detected.

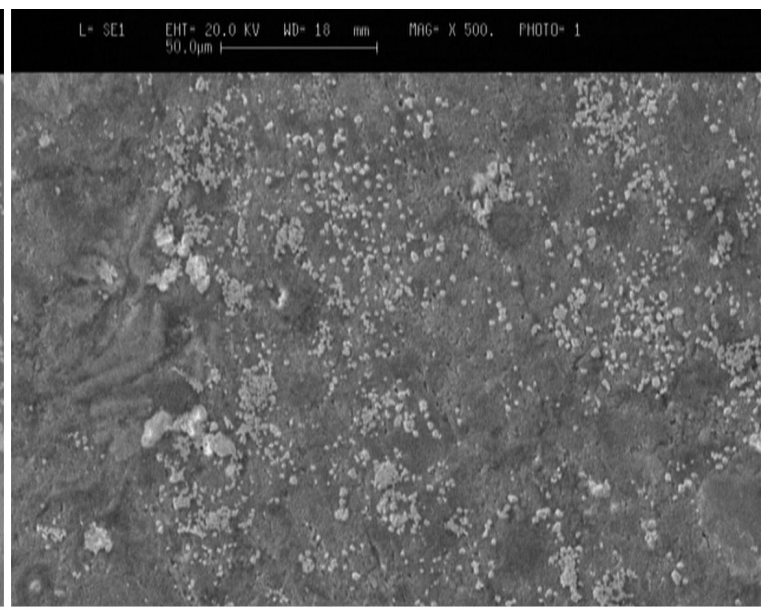

(b)

Figure 5. SEM micrographs of A series of samples sintered at $750^{\circ} \mathrm{C}$ in conventional furnace: (a) Backscattered and (b) secondary electron. 
Surayanarayana has shown that one of these phases is identical in structure with the equilibrium phase $\mathrm{Al}_{12} \mathrm{~W}^{[13]}$. Probably due to higher $\mathrm{W}$ content the lattice parameter of the bcc cell is greater. The second phase mentioned by Tonejc ${ }^{14}$ has tetragonal structure and also the stoichiometry $\mathrm{Al}_{12} \mathrm{~W}$.

Table 2. Crystal structure and lattice parameters of intermediate phases $^{13,14}$.

\begin{tabular}{cccclc}
\hline phase & Structure & Type & $\mathbf{a}[\mathbf{n m}]$ & $\mathbf{b}[\mathbf{n m}]$ & $\mathbf{c}[\mathbf{n m}]$ \\
\hline $\mathrm{Al}_{12} \mathrm{~W}$ & bcc & $\mathrm{Al}_{12} \mathrm{~W}$ & & & \\
$\mathrm{Al}_{12} \mathrm{~W}$ & tetr & & & 0.7874 & \\
$\mathrm{Al}_{5} \mathrm{~W}$ & hex & $\mathrm{Al}_{5} \mathrm{Mo}$ & & 0.88578 & \\
$\mathrm{Al}_{4} \mathrm{~W}$ & mon & & 1.7771 & 0.5218 & 100.2 \\
\hline
\end{tabular}

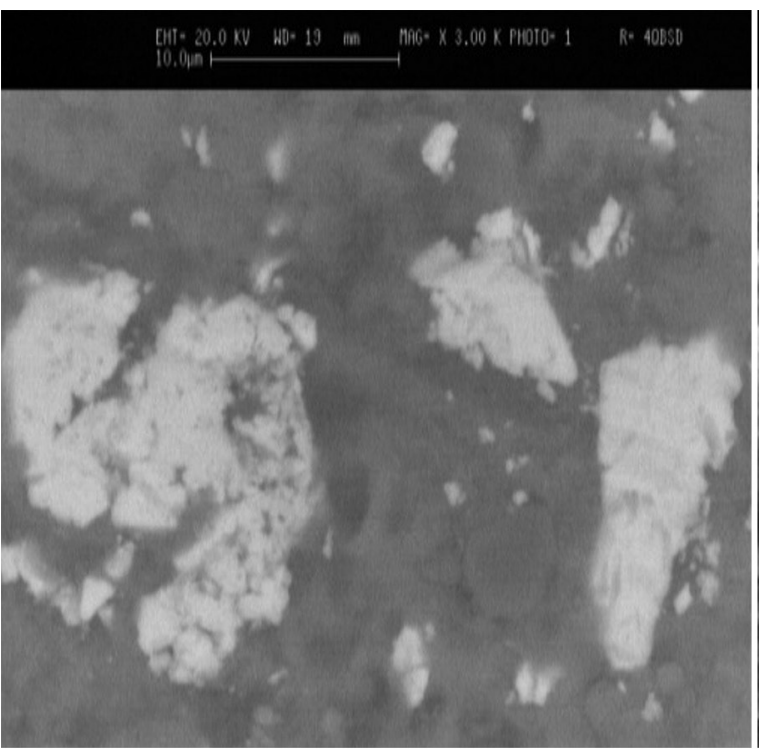

(a)
It seems that this tetragonal modification is stable above $870^{\circ} \mathrm{K}$. Probably on cooling, there occurs a polymorphic transformation into the bcc structure.

Figure 5 illustrates SEM micrographs of A series of samples sintered at $750{ }^{\circ} \mathrm{C}$ in conventional furnace, showing a nearly homogeneous distribution of reinforcements in the aluminum matrix.

Figures 6 and 7 show SEM micrographs of A series of samples sintered in microwave furnace at 650 and $750{ }^{\circ} \mathrm{C}$, respectively. Figure 6 shows an appropriate interface between $\mathrm{Al}$ and $\mathrm{WC}$ reinforcement particles which provides an optimal structure in terms of mechanical properties.

By increasing sintering temperature near the melting of aluminum $\left(660^{\circ} \mathrm{C}\right)$, more aluminum particles are surrounded by the substantial oxide film $\left(\mathrm{Al}_{2} \mathrm{O}_{3}\right)$ until the sintering

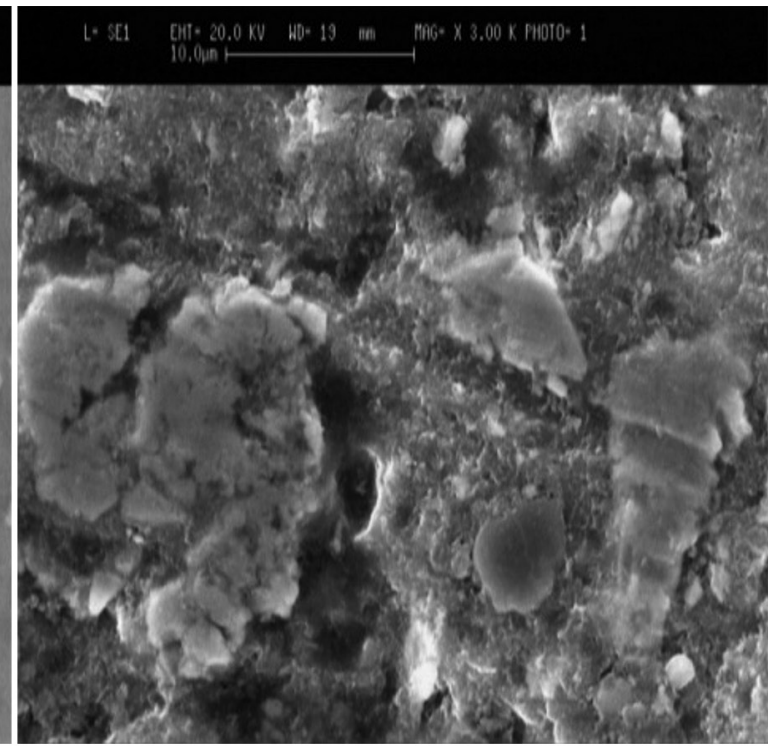

(b)

Figure 6. SEM micrographs of A series of samples sintered at $650{ }^{\circ} \mathrm{C}$ in microwave furnace: (a) Backscattered and (b) secondary electron.

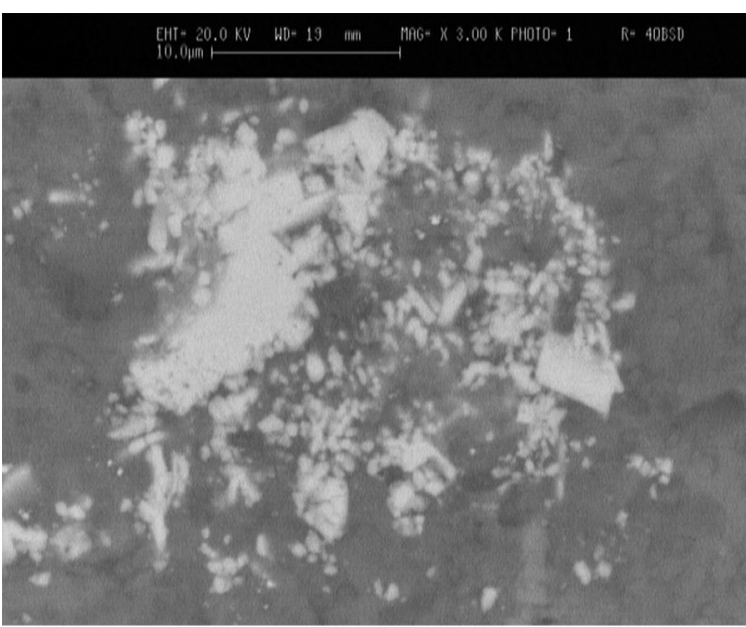

(a)

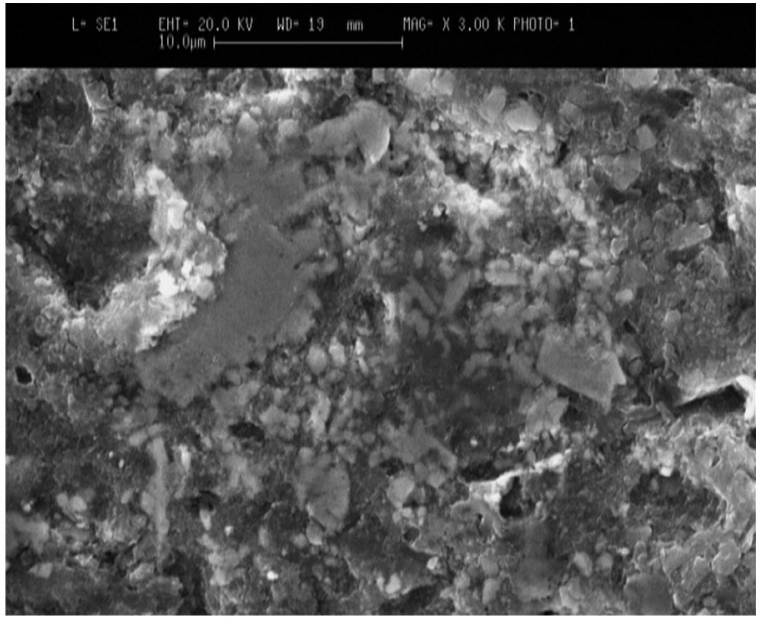

(b)

Figure 7. SEM micrographs of A series of samples sintered at $750{ }^{\circ} \mathrm{C}$ in microwave furnace: (a) backscattered and (b) secondary electron. 
temperature goes beyond the melting temperature of aluminum. The aluminum particles begin to melt and their volumes increase and become large enough to smash the oxide layer, making contact and then weld of leaked aluminum particles ${ }^{15}$. Some samples were sintered at temperatures greater than the melting point of aluminum which implies that WC particles prevent aluminum particles from getting too close to one another. Apart from the interfacial reaction between $\mathrm{Al}$ and WC particles, with the increase in the sintering temperature the agglomeration of WC particles, which is detrimental for mechanical properties, was increased (Figure 7). However, as discussed previously, the higher sintering temperature caused in higher relative density.

Figures 8 and 9 presents the effect of sintering temperature on the bending strength of samples sintered in microwave and conventional furnace, respectively.

The results were clearly shown that the bending strength in microwave sintered samples had the same trend with increasing WC composition for all sintering temperatures (Figure 9). The highest amounts of bending strength for all compositions were obtained by A series which had higher relative density among others. With the increase in sintering temperature, the bending strength values ( $\pm 12 \mathrm{MPa}$ standard deviation) increased due to the increase of the agglomeration of reinforcement particles at sintering temperatures over $650^{\circ} \mathrm{C}$.

The bending strength values of composites (Figure 9) varied with the increase in sintering temperature and had

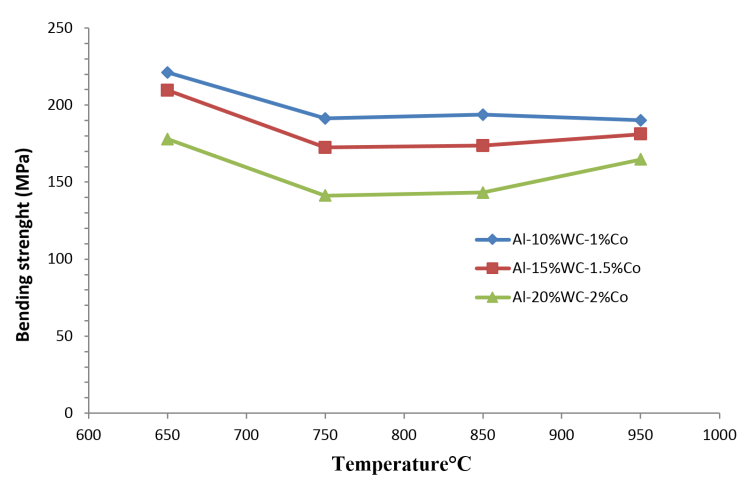

Figure 8. The variations of bending strength values with sintering temperature in conventionally sintered samples.

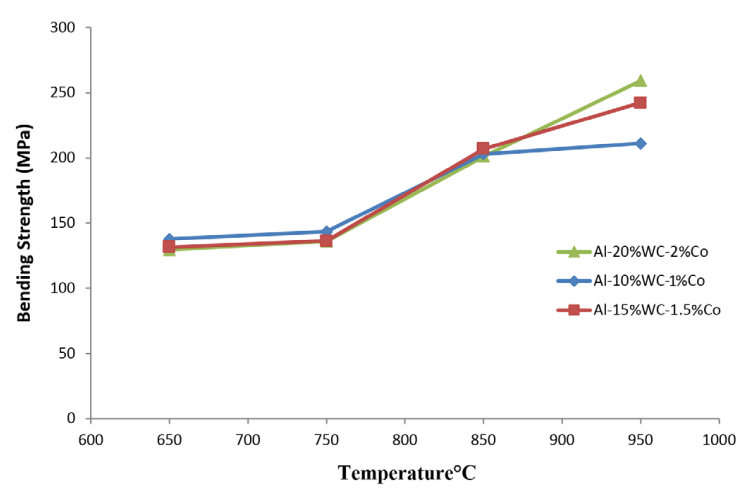

Figure 9. The variations of bending strength values with sintering temperature in microwave sintered samples. similar changes to values obtained by relative density measurements (Figure 2). The maximum bending strength obtained at $950{ }^{\circ} \mathrm{C}$ for $\mathrm{C}$ series which had the highest relative density among all specimens. Maybe the formation of $\mathrm{Al}_{5} \mathrm{~W}$ phase had a positive effect on bending strength of samples sintered at evaluated temperatures but this phenomenon was not observed in microwave sintered samples due to the influence of other parameters on bending strength such as the distribution of reinforcements, relative density and etc.

As comparison between the result of this research and other aluminum matrix composite, the bending strength of $\mathrm{ZnO}$ coated aluminum borate whiskers reinforced $2024 \mathrm{Al}$ composites were calculated by Yue et al. ${ }^{16}$. The results were shown by them revealed that the optimum bending strength was $480 \pm 20 \mathrm{MPa}$. On the other hand, the optimum bending strength as result of this work is $256 \pm 12 \mathrm{MPa}$ which had almost identical reinforcement amounts compared with $\mathrm{ZnO}$ coated aluminum borate whiskers reinforced $2024 \mathrm{Al}$ composites, demonstrate that the mechanical properties obtained by this work is considerable. The mentioned composite were fabricated by Yue et al., used coated whiskers as reinforcement have effective role in mechanical properties (specially bending strength). But in this work applying particulate reinforcement conducted to comparable result with simple starting materials and appropriate preparation process considering time and energy saving.

\section{Conclusions}

The considerable conclusions of the studies on Al-WC metal matrix composites are as follows:

1. Al-WC composites were prepared successfully using microwave and conventional techniques with the highest relative density of $97.4 \pm 1.2 \%$ and $98.6 \pm 0.8$, respectively.

2. It was found that the decomposition of $\mathrm{WC}$ and also the formation of $\mathrm{Al}_{5} \mathrm{~W}$ and $\mathrm{Al}_{12} \mathrm{~W}$ (interfacial reaction products) in microwave and conventional sintering occurred at 650 and $850{ }^{\circ} \mathrm{C}$, respectively.

3. The SEM micrographs showed uniform distribution of reinforcements in conventional process and agglomeration of reinforcements in microwave process at the early stage of sintering.

4. The maximum bending strength of $223 \pm 12$ and $256 \pm 12 \mathrm{MPa}$ was obtaimned in microwave sintered sample $\left(10 \mathrm{wt} \% \mathrm{WC}\right.$ at $\left.650{ }^{\circ} \mathrm{C}\right)$ and conventional sintered sample $(20 \mathrm{wt} \% \mathrm{WC}$ at $\left.950{ }^{\circ} \mathrm{C}\right)$, respectively.

5. Almost the higher mechanical properties were achieved by conventional sintering compared to microwave sintering; while microwave sintering had the best advantage of time and energy saving with acceptable properties. 


\section{References}

1. Nie C-Z, Gu J-J, Liu J-L and Zhang D. Production of boron carbide reinforced 2024 aluminum matrix composites by mechanical alloying. Materials Transactions. 2007; 48(5):990995. http://dx.doi.org/10.2320/matertrans.48.990.

2. Gnanasundarajayaraja B. Effect of WC content in Aluminum metal matrix sintered powder composites. European Journal of Scientific Research. 2012; 82(1):9-16.

3. Rana RS, Purohit R and Das S. Review of recent studies in Al matrix composites. International Journal of Scientific \& Engineering Research. 2012; 3(6):1-16.

4. Evirgen A and Öveçoğlu ML. Characterization investigations of a mechanically alloyed and sintered $\mathrm{Al}-2 \mathrm{wt} \% \mathrm{Cu}$ alloy reinforced with WC particles. Journal of Alloys and Compounds. 2010; 496(1-2):212-217. http://dx.doi.org/10.1016/j.jallcom.2010.02.136.

5. Abdizadeh H, Baharvandi HR and Moghaddam KS. Comparing the effect of processing temperature on microstructure and mechanical behavior of $\left(\mathrm{ZrSiO}_{4}\right.$ or $\left.\mathrm{TiB}_{2}\right)$ /aluminum composites. Materials Science and Engineering A. 2008; 498(1-2):53-58. http://dx.doi.org/10.1016/j.msea.2008.07.009.

6. Abdizadeh H, Ashuri M, Moghadam PT, Nouribahadory A and Baharvandi HR. Improvement in physical and mechanical properties of aluminum/zircon composites fabricated by powder metallurgy method. Materials \& Design. 2011; 32(8-9):44174423. http://dx.doi.org/10.1016/j.matdes.2011.03.071.

7. Babalola PO, Bolu CA, Inegbenebor AO and Odunfa KM. Development of aluminium matrix composites: a review. Journal of Engineering and Technology Research. 2014; 2:1-11.

8. Casati R and Vedani M. Metal matrix composites reinforced by nano-particles: a review. Metals. 2014; 4(1):65-83. http:// dx.doi.org/10.3390/met4010065.
9. Shulman HS, Fall ML, Walker WJ Jr, Treado TA, Evans SJ, Marks $\mathrm{M}$, et al. Sintering uniformity and reproducibility with $2.45 \mathrm{ghz}$ microwaves in an industrial sized chamber. In: Proceedings of the 104th Annual Meeting of the American Ceramic Society; 2002; St. Louis, MO. Hoboken: John Wiley \& Sons; 2002. p. 5-11.

10. Takayama S, Saiton Y, Sato M, Nagasaka T, Muroga T and Ninomiya Y. Microwave sintering for metal powders in the air by non-thermal effect. In: Proceedings of the 9 th Conference on Microwave and High Frequency Heating; 2003; Loughborough, UK. Loughborough: Loughborough University; 2003. p. 369372.

11. Roy R, Agrawal D, Cheng J and Gedevanishvili S. Full sintering of powdered-metal bodies in a microwave field. Nature. 1999; 399(6737):668-670. http://dx.doi.org/10.1038/21390.

12. Liang Q, Mao C, Jian Y and Jun D. Analyse of the interfacial reaction inWCp/2024 Al composites. Powder Metallurgy Technology. 2009; 27(5):327-330.

13. American Society for Metals-ASM. Metallography, structures and phase diagrams. 8th ed. Ohio: ASM; 1973. Metals Handbook, 8.

14. Tonejc A. Phase transformations in Al-rich Al-W alloys rapidly quenched from the melt. Journal of Materials Science. 1972; 7(11):1292-1298. http://dx.doi.org/10.1007/BF00550695.

15. Khairaldien WM, Khalil AA and Bayoumi MR. Production of aluminum-silicon carbide composites using powder metallurgy at sintering temperatures above the aluminum melting point. Journal of Testing and Evaluation. 2007; 35(6):1-13.

16. Yue HY, Zhang H, Gao X, Chang J, Zhang SL, Zhang JJ, et al. Bending properties and fracture behaviors of $\mathrm{ZnO}$ coated aluminum borate whiskers reinforced 2024Al composites. Materials Characterization. 2015; 99:47-51. http://dx.doi. org/10.1016/j.matchar.2014.11.010. 